\title{
MULTIVARIATE EVALUATION OF VARIABILITY OF BROMUS GENOTYPES FROM NORTH-EASTERN POLAND
}

\author{
KUBICKA, H. ${ }^{1}-$ GOZDOWSKI, D. ${ }^{2 *}-$ SKRAJNA, T. ${ }^{3}$ \\ ${ }^{1}$ Polish Academy of Sciences, Botanical Garden - Center for Biological Diversity Conservation \\ Powsin, Prawdziwka 2, 02-973 Warsaw, Poland \\ (phone: + 48-22-648-38-56; fax: +48-22-757-66-45) \\ ${ }^{2}$ Warsaw University of Life Sciences, Department of Experimental Design and Bioinformatics \\ Nowoursynowska 159, 02-776 Warsaw, Poland \\ (phone: +48-22-59-32-730; fax: +48-22-59-32-506) \\ ${ }^{3}$ Agricultural Ecology Department, University of Natural Sciences and Humanities \\ Prusa 14, 08-110 Siedlce, Poland \\ (phone: + 48-25-643-13-01) \\ *Corresponding author \\ e-mail: dariusz_gozdowski@sggw.pl \\ (Received $16^{\text {th }}$ Jan 2013; accepted $28^{\text {th }}$ Aug 2014)
}

\begin{abstract}
In the years 2008-2010 phenotypic observations of the populations of Bromus secalinus L. at 14 sites in North-Eastern Poland were carried out. The populations were characterised by measurements of the following parameters: tuft height, number of culms in a tuft, height of generative shoots, length of panicle, number of spikelets in panicle, number of kernels in spikelet, number of kernels in panicle and seed production per plants. Cluster analysis by the Ward method distinguished 4 groups of genotypes of multivariate similar populations of rye brome. The greatest distances between the values of characters analysed were found between groups 1 and 4 . On the basis of spatial autocorrelation analysis a significant autocorrelations for height of generative shoots, length of panicle and number of spikelets in panicle was found, which means that these traits were similar for spatially close populations.
\end{abstract}

Keywords: autocorrelations, Bromus, genotypes, multivariate, spatial, variability

\section{Introduction}

Over recent years a decrease in genetic diversity in segetal communities has been observed. This phenomenon leads to the disappearance of species characteristic of a given field agrocenosis and spreading of nitrophilous taxa, including those from Poaceae family (Peterson, 2006). The changes are interpreted as consequences of changes in the conditions of plat vegetation related to the new technologies of field production including the use of herbicides. As a result the appearance of the impoverished communities is observed, in which one or two species dominate (Pysek et al., 2005; Baessler and Klotz, 2006; Pinke and Pál, 2008; Holubec, 2010). In Poland about 100 species of field weeds have the status of threatened with extinction (Warcholińska, 1994). According to Siciński (2001), over the last 50 years not only the number of weed species but also the bank of their diaspores in soil have decreased by $20-40 \%$. In view of the above, measures should be taken to restrict this phenomena by setting up agro-reserves as it has been done in West European countries. It seems a good idea to leave small enclaves in which segetal species should have their ecological niche.

The existing populations of threatened segetal species should be monitored and favourable conditions should be made for their development. Prior to taking up these 
measures, the genetic diversity of the threatened species should be evaluated on the sites of their occurrence to establish the degree of inbred and assess the narrowing of the genetic pool.

It is known that genetically homogeneous populations are to a greater degree threatened with extinction as individuals of the same genetic composition have the same resistance to adverse environmental factors such as diseases or pests, which can lead to their fast elimination. Within the large project aimed at protecting biodiversity in Poland, we wanted to emphasise the situation of segetal community species, especially those threatened with extinction.

The aim of the study undertaken was to evaluate the phenotypic variation of rye brome populations in North-Eastern Poland. In particular we wanted to establish the degree of genetic diversity of populations of this species and to check if similar genotypes occur in spatially close localities.

\section{Material and methods}

\section{Area of study}

In the years 2008-2010 phenotypic analysis was made of Bromus secalinus L. populations occurring at 14 localities (Bryzgiel, Leszczewo, Magdalenowo, Horodnianka, Rzepiska, Gołaszyn, Rudnik, Popławy, Niwiski, Bojmie, Jagodne, Groszki Stare, Barcząca and Tyborów) in North-Eastern Poland. The area studied covered about $250,000 \mathrm{~km}^{2}$ (Fig. 1).

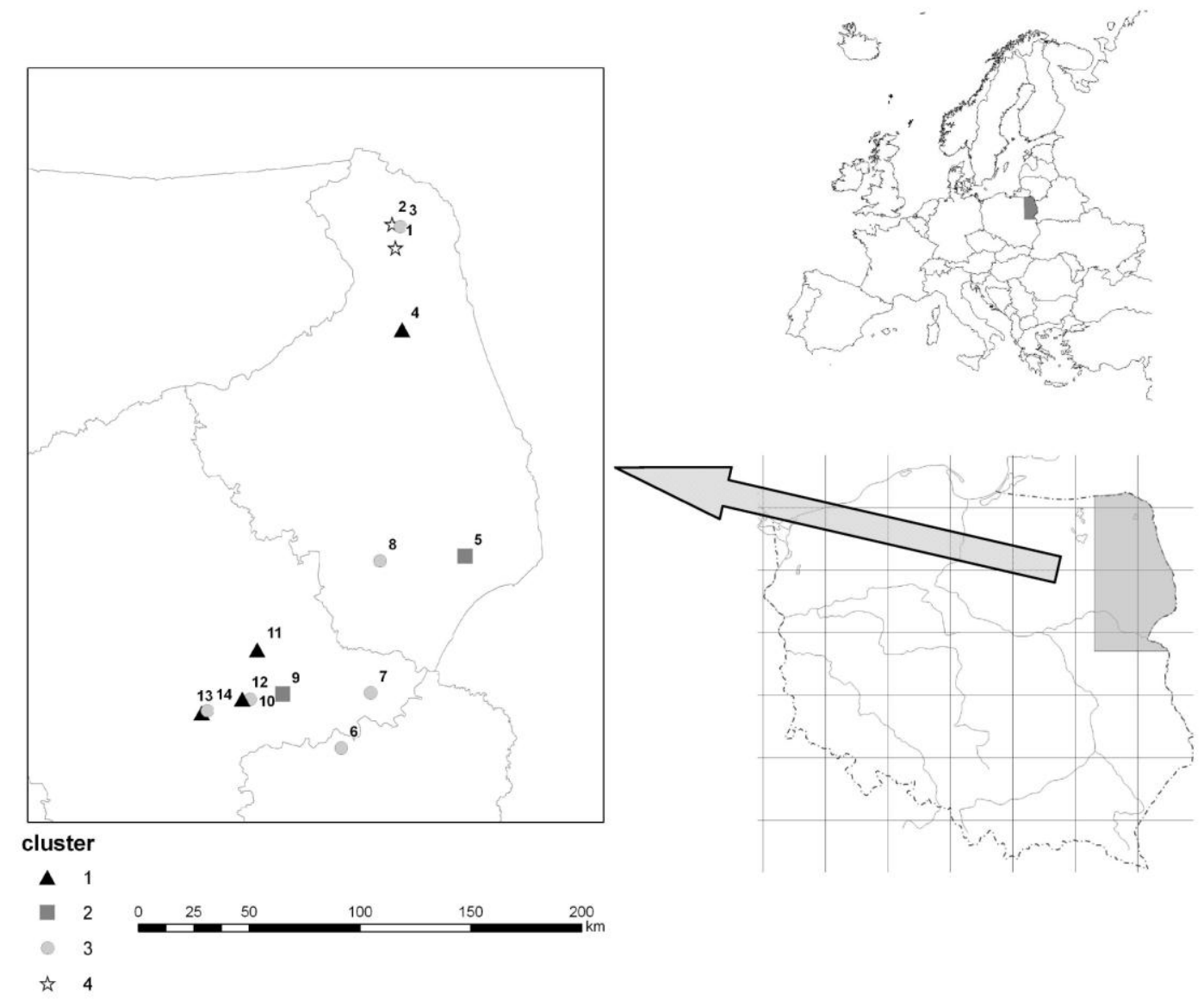

Figure 1. Location of study area and distinguished groups of genotypes in the sites. 
In the phase of wax maturity 30 plants of $\mathrm{B}$. secalinus were collected from each site and for them the following traits were measured: tuft height, number of culms in a tuft, height of generative shoots, length of panicle, number of spikelets in panicle, number of kernels in spikelet, number of kernels in panicle and seed production per plants. Results are presented as mean values and the range of variation, the coefficient of variation (CV) was calculated.

\section{Statistical analysis}

The collected data were used for univariate and multivariate statistical analysis. For each location basic statistical parameters were calculated i.e. means, ranges of values and coefficients of variations (standard deviations/mean).

For further multivariate statistical analyses means for each location were used (Johnson and Wichern, 2002). Cluster analysis was used for distinguishing similar genotypes based on eight traits. Square Euclidean distance was used as a measure of dissimilarity between the genotypes and Ward's method was used for agglomeration of the object into groups. The analyses were performed on standardized variables.

Means for the same traits were used for principal component analysis (PCA) to describe relations between the examined traits and to present multivariate variability of the genotypes.

Spatial statistics were used for estimation of spatial autocorrelation. For each trait Moran's I autocorrelation coefficient was calculated (Moran 1950; Mitchell, 2005).

For the analyses Statistica 8.0 (StatSoft, 2008) statistical package and ArcGIS 9.3 (ESRI) geografic information system software were used. For all analyses significance level was set at 0.05 .

\section{Results}

Between the examined traits the highest relative variability expressed by coefficient of variation (CV) was observed for seed reproduction (Table 1). Coefficient of variability for all locations was equal to $127.8 \%$ and was from about $50 \%$ (sites: 2, 3, 6 and 7) to more than $200 \%$ (site number 5). High variability was observed for number culms in tuft. Coefficient of variation for this trait for all data set was equal to $91.6 \%$ and for examined sites was from 32 to $140 \%$. The trait with the lowest variability was tuft height; CV for all data set was equal $17.1 \%$ and for examined sites was between 7 and $22 \%$. Quite low relative variability was observed for number of kernels in spikelet and height of generative shoots. CV for number of kernels in spikelet was equal to $23.2 \%$ for all data set and $22.4 \%$ for height of generative shoots. For both traits range of $\mathrm{CV}$ for examined sites was between 10 and $30 \%$.

On the basis of Ward's method of cluster analysis performed using mean values of eight traits 4 groups of genotypes were distinguished. The four groups are presented in the dendrogram (Fig. 2). To the first group belong four genotypes from following sites: $4,11,12$ and 13. The group is characterized by the lowest means of all examined traits i.e. traits described height of plants and shoots as well traits connected with yielding of plants had much lower means in comparison with other groups of genotypes (Table 2). 
Table 1. Mean values, variability range and coefficient variability of studied features in Bromus

\begin{tabular}{|c|c|c|c|c|c|c|c|c|c|c|c|c|}
\hline \multirow[b]{2}{*}{ Location } & \multicolumn{3}{|c|}{ Tuft height } & \multicolumn{3}{|c|}{ Number culm in tuft } & \multicolumn{3}{|c|}{ Height of generative shoots } & \multicolumn{3}{|c|}{ Seed reproduction } \\
\hline & $\begin{array}{l}\text { Min - } \\
\max \end{array}$ & Mean & CV & $\begin{array}{l}\text { Min - } \\
\max \end{array}$ & Mean & CV & $\begin{array}{l}\text { Min - } \\
\max \end{array}$ & Mean & CV & $\begin{array}{l}\text { Min - } \\
\max \end{array}$ & Mean & CV \\
\hline 1-Bryzgiel & $119-153$ & $138=10.6$ & 7.7 & $2-12$ & $4.5 \pm 2.5$ & 55.1 & $105-143$ & $124.7 \pm 10.3$ & 8.3 & $230-1450$ & $601.8 \pm 341.7$ & 56.8 \\
\hline \multirow{2}{*}{$\begin{array}{l}\text { 2-Leszczewo } \\
\text { 3- } \\
\text { Magdalenowo }\end{array}$} & $126-153$ & $141 \pm 9.6$ & 6.8 & $2-12$ & $5.1 \pm 2.9$ & 56.3 & $116.2-143$ & $127.3 \pm 9.0$ & 7.1 & $230-1450$ & $739.9 \pm 425.4$ & 57.5 \\
\hline & $119-149$ & $134 \pm 9.2$ & 6.9 & $1-6$ & $3.7 \pm 1.2$ & 32.2 & $99-142$ & $118.7 \pm 11.4$ & 9.6 & $154-1005$ & $441.8 \pm 228.1$ & 51.6 \\
\hline 4-Horodnianka & $70-142$ & $110=19.7$ & 17.9 & $1-11$ & $2.5 \pm 2.6$ & 106.3 & $70-128.5$ & $104.7 \pm 17.5$ & 16.7 & $20-1702.2$ & $280.3 \pm 401.2$ & 143.1 \\
\hline 5-Rzepiska & $97-149$ & $120 \pm 14.2$ & 11.9 & $1-19$ & $3.9 \pm 4.3$ & 112 & $55.3-141$ & $96.2 \pm 24.6$ & 25.5 & $45-3615$ & $463 \pm 942.9$ & 203.6 \\
\hline 6-Golaszyn & $85-136$ & $115 \pm 14.3$ & 12.4 & $1-4$ & $2.3 \pm 1.2$ & 50.8 & $62.7-136$ & $102.7 \pm 22.2$ & 21.7 & $40-420$ & $220.2 \pm 97.9$ & 44.4 \\
\hline 7-Rudnik & $92-145$ & $122 \pm 13.6$ & 11.2 & $1-7$ & $2.1 \pm 1.7$ & 79.5 & $10.6-135$ & $101.1 \pm 29.6$ & 29.3 & $60-529$ & $201.9 \pm 107.3$ & 53.2 \\
\hline 8-Poplawy & $102-146$ & $126 \pm 15.1$ & 11.9 & $1-10$ & $2.9 \pm 2.8$ & 95.1 & $60.7-145$ & $100.6 \pm 23.5$ & 23.4 & $56-898$ & $290.5 \pm 237.8$ & 81.8 \\
\hline 9-Niwiski & $89-155$ & $129 \pm 17.1$ & 13.3 & $1-24$ & $4.4 \pm 6.2$ & 139.6 & $38.7-147$ & $105.4 \pm 28.3$ & 26.9 & $20-3185$ & $511.7 \pm 898.0$ & 175.5 \\
\hline 10-Bojmie & $90-153$ & $127 \pm 17.5$ & 13.7 & $1-9$ & $2.7 \pm 1.8$ & 66.5 & $46.5-155$ & $106 \pm 27.3$ & 25.8 & $51-1568$ & $273.6 \pm 286.2$ & 104.6 \\
\hline \multirow{2}{*}{$\begin{array}{l}\text { 11-Jagodne } \\
\text { 12-Groszki } \\
\text { Stare }\end{array}$} & $59-120$ & $85 \pm 18.3$ & 21.6 & $1-6$ & $2.9 \pm 1.5$ & 52.3 & $44.2-113$ & $77 \pm 19.3$ & 25 & $15-720$ & $196.7 \pm 176.1$ & 89.5 \\
\hline & $80-135$ & $109=13.8$ & 12.6 & $1-4$ & $1.9=1.0$ & 50.5 & $73-135$ & $99.4 \pm 15.0$ & 15.1 & $30-420$ & $137.3 \pm 82.4$ & 60.0 \\
\hline 13-Barczaca & $60-141$ & $105 \pm 17.8$ & 16.9 & $1-13$ & $3.5 \pm 3.4$ & 98.1 & $60-121.6$ & $97.5 \pm 16.0$ & 16.4 & $12-1928$ & $345.7 \pm 448.8$ & 129.8 \\
\hline 14-Tyborów & $78-142$ & $117 \pm 15.4$ & 13.1 & $1-10$ & $3.2 \pm 2.6$ & 80.7 & $68.3-137$ & $105.7 \pm 17.2$ & 16.2 & $21-1206$ & $354.6 \pm 286.1$ & 80.7 \\
\hline \multirow[t]{2}{*}{ total } & $59-155$ & $120 \pm 20.5$ & 17.1 & $1-24$ & $3.3 \pm 3.0$ & 91.6 & $10.6-155$ & $104.8 \pm 23.5$ & 22.4 & $12-3615$ & $361.4 \pm 461.9$ & 127.8 \\
\hline & \multicolumn{3}{|c|}{ Length of panicle } & \multicolumn{3}{|c|}{ Number of spikelets in panicle } & \multicolumn{3}{|c|}{ Number of kernels in panicle } & \multicolumn{3}{|c|}{ Number of kernels in spikelet } \\
\hline Location & $\begin{array}{c}\text { Min - } \\
\max \end{array}$ & Mean & CV & $\begin{array}{c}\text { Min - } \\
\max \end{array}$ & Mean & CV & $\begin{array}{c}\text { Min - } \\
\max \end{array}$ & Mean & CV & $\begin{array}{c}\text { Min - } \\
\max \end{array}$ & Mean & CV \\
\hline 1-Bryzgiel & $11-22.2$ & $16.1 \pm 2.5$ & 15.7 & $10-39$ & $20.7 \pm 6.8$ & 33 & $74-235$ & $136.7 \pm 40.9$ & 29.9 & $5.3-7.8$ & $6.7 \pm 0.7$ & 10.8 \\
\hline \multirow{2}{*}{$\begin{array}{l}\text { 2-Leszczewo } \\
\text { 3- } \\
\text { Magdalenowo }\end{array}$} & $14-22.2$ & $17.2 \pm 2.2$ & 12.6 & $12-39$ & $21.3 \pm 7.2$ & 33.8 & $76-235$ & $142.2 \pm 40.2$ & 28.3 & $5.3-7.8$ & $6.8 \pm 0.8$ & 12.5 \\
\hline & $10-20.2$ & $15.1 \pm 3.0$ & 19.5 & $9-31$ & $19.4 \pm 6.5$ & 33.3 & $57-210$ & $118.9 \pm 42.6$ & 35.8 & $4.2-7.1$ & $6 \pm 0.9$ & 15.1 \\
\hline 4-Horodnianka & $5-18$ & $12.8 \pm 3.3$ & 25.9 & $4-29.7$ & $15.5 \pm 7.6$ & 49.2 & $20-168$ & $81 \pm 41.5$ & 51.3 & $4.0-6.0$ & $5.1 \pm 0.6$ & 11.0 \\
\hline 5-Rzepiska & $7.3-16$ & $11.4 \pm 2.6$ & 22.5 & $4.6-30$ & $13.8 \pm 7.3$ & 52.5 & $2-255$ & $87.6 \pm 64.3$ & 73.5 & $2.8-11.0$ & $6.6 \pm 1.5$ & 23.1 \\
\hline 6-Golaszyn & $8-25$ & $14.4 \pm 4.8$ & 32.9 & $8.3-37$ & $19.6 \pm 7.0$ & 35.8 & $40.8-240$ & $113.1 \pm 56.6$ & 50 & $4.0-8.0$ & $5.5 \pm 1.0$ & 18.9 \\
\hline 7-Rudnik & $6.3-18$ & $12.5 \pm 2.9$ & 23.5 & $10.6-31$ & $20 \pm 6.5$ & 32.5 & $40-232$ & $121 \pm 52.8$ & 43.7 & $3.6-8.0$ & $5.8 \pm 1.2$ & 19.8 \\
\hline 8-Poplawy & $6-17$ & $10.8 \pm 3.4$ & 31.3 & $11-34$ & $18.2 \pm 8.0$ & 44 & $56-374$ & $145.1 \pm 91.5$ & 63.1 & $4.0-11.1$ & $6.2 \pm 1.9$ & 31 \\
\hline 9-Niwiski & $6-18$ & $12.4 \pm 3.0$ & 24.1 & $4-31$ & $14.8 \pm 6.9$ & 46.5 & $15-266$ & $101.4 \pm 64.7$ & 63.8 & $2.7-12.0$ & $6.5 \pm 2.0$ & 31.1 \\
\hline 10-Bojmie & $1.5-22$ & $13 \pm 4.8$ & 37.1 & $3.7-39$ & $15.2 \pm 7.7$ & 50.8 & $9-234$ & $105.2 \pm 60.8$ & 57.8 & $1.7-9.5$ & $6.4 \pm 1.9$ & 29.7 \\
\hline \multirow{2}{*}{$\begin{array}{l}\text { 11-Jagodne } \\
12-\text { Groszli } \\
\text { Stare }\end{array}$} & $4.4-15.5$ & $10.1 \pm 3.1$ & 31.2 & $3-26$ & $11.2 \pm 6.2$ & 55.4 & $9-176$ & $68.3 \pm 45.9$ & 67.2 & $2.9-9.0$ & $5.8 \pm 1.2$ & 20.7 \\
\hline & $8.5-17$ & $12.3 \pm 2.3$ & 18.8 & $7-23$ & $14.1=4.8$ & 34.1 & $30-142$ & $75.1 \pm 32.2$ & 43 & $4.0-6.6$ & $5.4 \pm 0.7$ & 12.2 \\
\hline 13-Вarczaca & $4-27$ & $12.3 \pm 3.9$ & 31.4 & $3-47$ & $14.9=8.8$ & 58.7 & $12-313$ & $85.9=58.4$ & 68 & $4.0-7.4$ & $5.5 \pm 0.9$ & 15.7 \\
\hline 14-Tyborów & $6.5-23$ & $14.7 \pm 3.7$ & 25.3 & $2.6-36$ & $19.6 \pm 7.7$ & 39 & $13-309.6$ & $119.3 \pm 71.4$ & 59.9 & $4.2-13.6$ & $6.4 \pm 1.9$ & 28.9 \\
\hline total & $1.5-27$ & $13.2 \pm 3.8$ & 29.0 & $2.6-47$ & $17 \pm 7.6$ & 44.9 & $2-374$ & $107.2 \pm 60.7$ & 56.7 & $1.7-13.6$ & $6.1 \pm 1.4$ & 23.2 \\
\hline
\end{tabular}

The second group contains genotypes from sites number 5 and 9. These genotypes had quite low means of most traits in exception of number culms in tuft, number of kernels in spikelet and seed reproduction. In the third group are genotypes from six sites; these genotypes had quite low number culms in tuft and seed reproduction and quite high means for length of panicle, number of kernels in panicle and number of kernels in spikelet. Group 4 contain genotypes from two sites; the genotypes characterize the highest means for all traits. Especially very high mean was observed for seed reproduction, which was much higher in comparison with other groups; very high mean was observed for number culms in tuft.

Variability of examined population based on principal component analysis (PCA) is presented in Figure 3. Principal component analysis (PCA) proved strong relationships between all traits. All traits were negatively correlated with the first principal 
component (Fig. 4, Table 3), which explained almost $70 \%$ of the total variability of all traits. The second principal component explained much less variability $(16.7 \%)$, it means that diversity of genotypes presented in plot of the first and the second principal components is mainly along X axis (PC1), in smaller degree along $\mathrm{Y}$ axis (PC2).

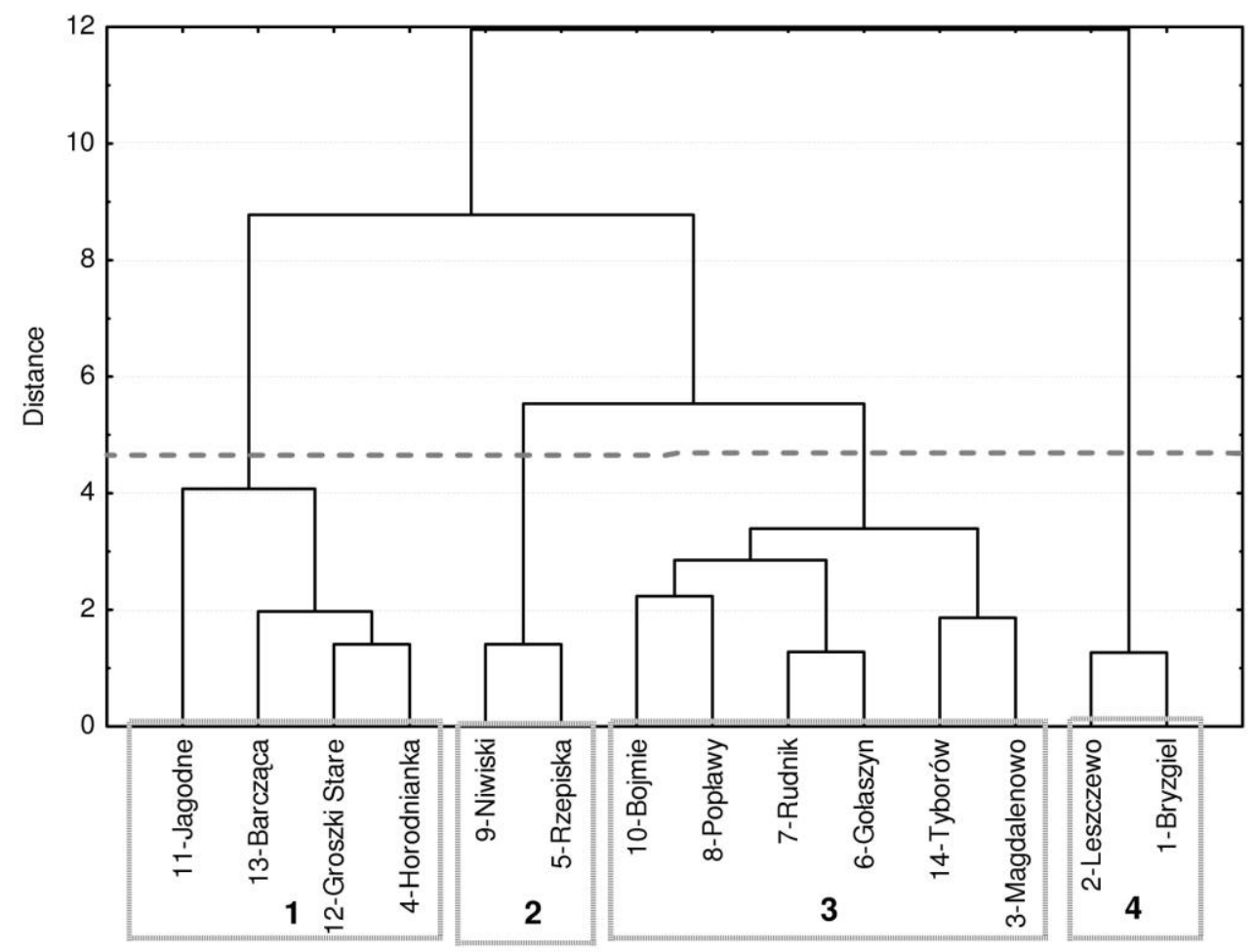

Figure 2. Dendrogram on the basis of cluster analysis with distinguished 4 groups of genotypes from the different sites

Table 2. Mean values and standard deviations for distinguished clusters in cluster analysis

\begin{tabular}{c|c|c|c|c}
\hline \multirow{2}{*}{ Features } & \multicolumn{4}{|c}{ Group } \\
\cline { 2 - 5 } Tuft height & $\mathbf{1}$ & $\mathbf{2}$ & $\mathbf{3}$ & $\mathbf{4}$ \\
\hline Number culms in tuft & $102.3 \pm 11.9$ & $124.3 \pm 6.3$ & $123.6 \pm 6.9$ & $139.1 \pm 2.2$ \\
Height of generative shoots & $2.68 \pm 0.66$ & $4.15 \pm 0.4$ & $2.84 \pm 0.59$ & $4.78 \pm 0.45$ \\
Length of panicle & $11.9 \pm 1.2$ & $11.9 \pm 0.7$ & $13.4 \pm 1.6$ & $16.7 \pm 0.8$ \\
Number of spikelets in panicle & $13.9 \pm 1.9$ & $14.3 \pm 0.7$ & $18.7 \pm 1.8$ & $21 \pm 0.5$ \\
Number of kernels in spikelet & $5.43 \pm 0.29$ & $6.54 \pm 0.06$ & $6.07 \pm 0.35$ & $6.76 \pm 0.08$ \\
Number of kernels in panicle & $77.6 \pm 7.6$ & $94.5 \pm 9.8$ & $120.4 \pm 13.4$ & $139.5 \pm 3.9$ \\
Seed reproduction & $240 \pm 92$ & $487 \pm 34$ & $297 \pm 89$ & $671 \pm 98$ \\
\hline
\end{tabular}

The biggest difference was observed between groups 1 and 4 which are located in opposite parts of the Figure 3. Positive correlation between the second principal component (PC2) and tuft height, height of generative shoots, length of panicle i.e. traits which describe plants habit was observed. Negative correlation was observed between PC2 and number culms in tuft, number of kernels in spikelet, seed reproduction i.e. 
traits connected with plant productivity. The genotypes which are located in the top of the figure characterize by higher productivity and lower height, while at the bottom are genotypes which have higher plants but less productive.

On the basis of Moran's I spatial autocorrelation it is possible to detect for which traits spatial dependence exists i.e. similar mean values of the traits in sites located in lower distance.

Significant autocorrelation was observed for height of generative shoots, length of panicle and number of spikelets in panicle (Table 4). These traits had similar values for neighbouring sites and the difference between means of these traits was higher for distant locations.

Table 3. Correlation of coefficients between the traits and the first and the second principal components

\begin{tabular}{l|c|c}
\hline Trait & PC1 & PC2 \\
\hline Tuft height & -0.91 & 0.09 \\
Number culm in tuft & -0.75 & -0.62 \\
Height of generative shoots & -0.92 & 0.20 \\
Length of panicle & -0.83 & 0.27 \\
number of spikelets in panicle & -0.79 & 0.56 \\
Number of kernels in spikelet & -0.74 & -0.47 \\
Number of kernels in panicle & -0.83 & 0.32 \\
Seed reproduction & -0.86 & -0.45 \\
\hline
\end{tabular}

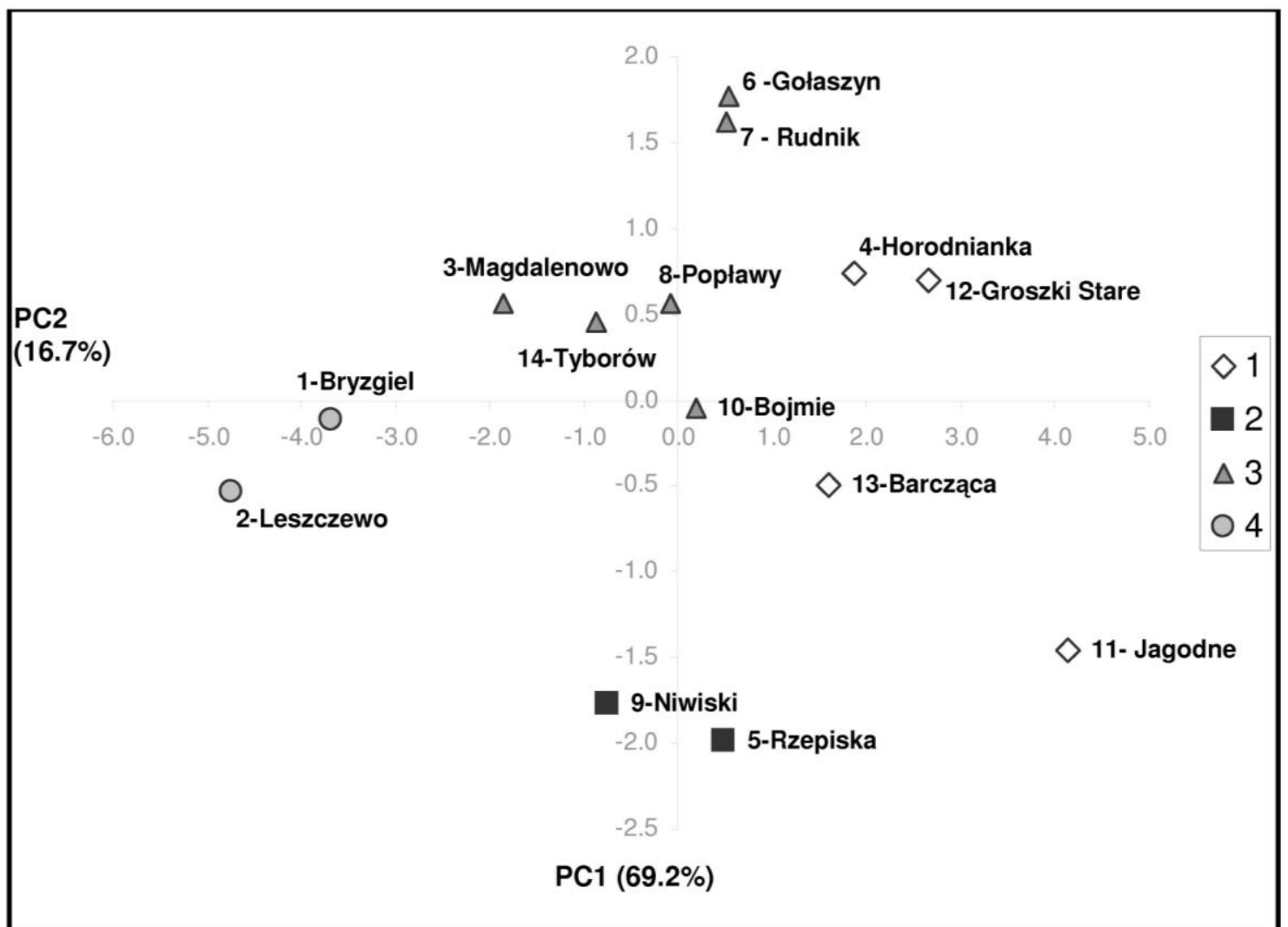

Figure 3. Plot of PC1 and PC2 for genotypes from examined locations 


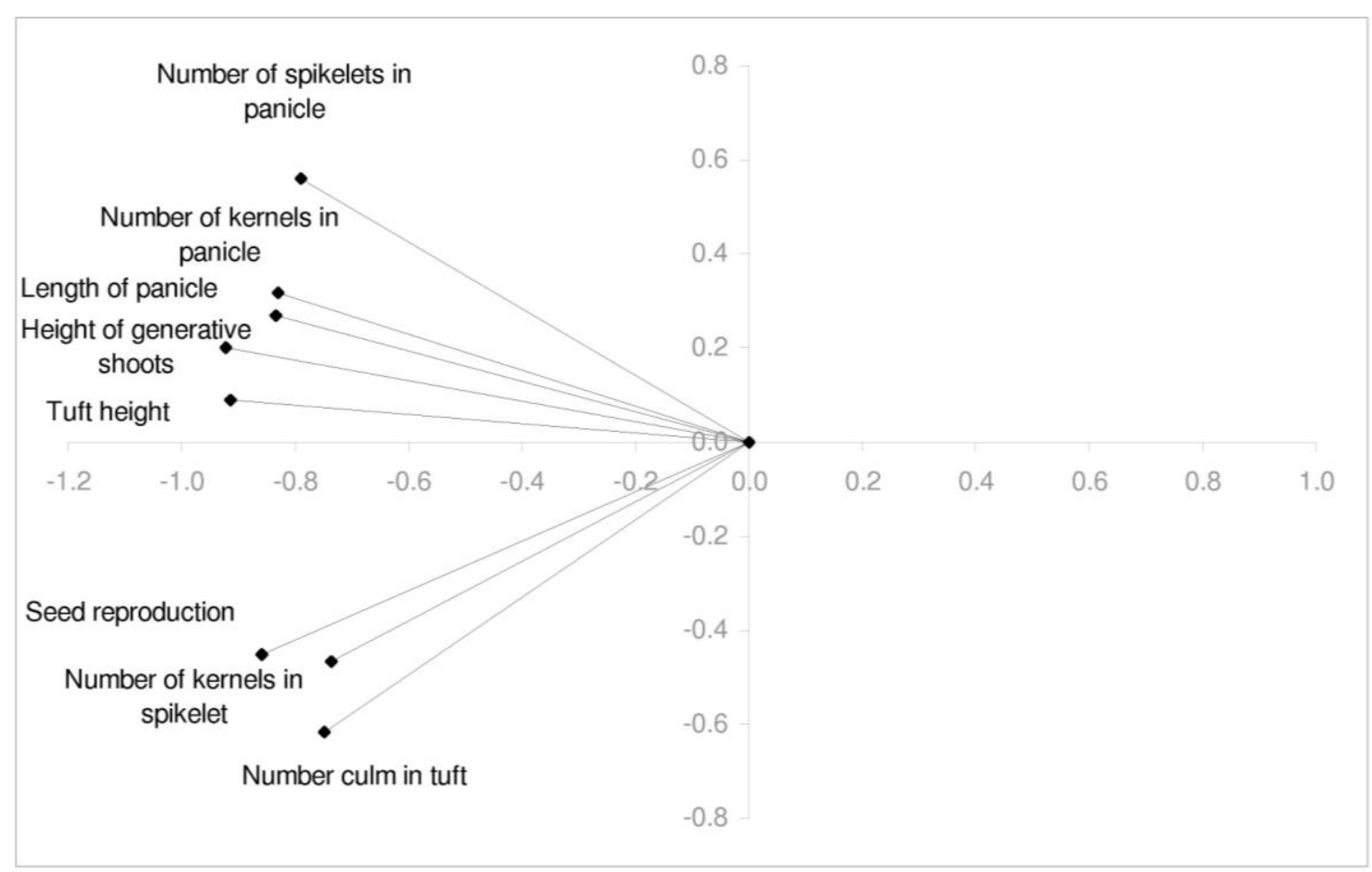

Figure 4. Investigated features in plot of two principal components (PC1 and PC2)

Table 4. Moran's I spatial autocorrelation coefficients

\begin{tabular}{l|l|c|c}
\hline & Trait & Moran's I & p-value \\
\hline X1 & Tuft height & 0.115 & 0.212 \\
X2 & Number culm in tuft & -0.020 & 0.727 \\
X3 & Height of generative shoots & 0.372 & 0.003 \\
X4 & Length of panicle & 0.303 & 0.019 \\
X5 & Number of spikelets in panicle & 0.279 & 0.031 \\
X6 & Number of kernels in spikelet & -0.231 & 0.350 \\
X7 & Number of kernels in panicle & 0.131 & 0.209 \\
X8 & Seed reproduction & 0.141 & 0.170 \\
\hline
\end{tabular}

$\mathrm{P}<0.05$ means significant spatial autocorrelation

\section{Discussion}

Bromus secalinus L. is an anthropogenic archeophyte, which means that its development has been stimulated by man by selection from parent populations (Zając et al., 2009). It is an annual tetraploidal species growing in fields with winter crop, especially in rye and wheat in Poland and its presence is related to extensive type of cultivation. It prefers moderately abundant, trophic habitats of $\mathrm{pH}$ weakly acidic or neutral (Zarzycki et al., 2002). Both in Poland and in other European countries rye brome has been also met on poor soils related to the community of Scleranthion anuuai (Šilc and Čarni, 2007). It is capable of adapting to non-segetal habitats, but there it occurs in less abundant populations. According to Warcholińska (1994) and Nowak et al. (2003), rye brome is threatened with extinction. However, in recent years an increase in the number of sites of its occurrence and in the number of individuals in populations 
of this species has been noted in the world (Stone et al., 2001; Moray, 2005) as well as in Poland, especially in eastern parts of Poland (Skrajna et al., 2005; Korniak and Dynowski, 2009; Skrajna et al., 2012).

Diversity of agrophytocenoses depends on many factors such as the climatic and soil conditions, culture of farming, technologies of cultivation and kind of crops (Tichonowa, 2007).

The rye brome populations studied differed significantly in the above traits as evidenced by high coefficients of variation. The lowest coefficients of variation were found to characterise the tuft height and generative shoot height, at three localities of rye brome (1,2 and 3). Taking into regard these traits, the three populations of rye brome showed a significant genetic homogeneity. So low coefficients of variation were noted in homozygous inbred lines (Kubicka and Dec, 2001) and some variations and local forms of rye (Kubicka et al., 2006). For rye, relatively high coefficients of variation were observed for hybrids, but the CV values were not higher than $50 \%$ (Kubicka et al., 2001).

The highest coefficients of variation were obtained for the number of set seeds, i.e. plant fertility, ranging from $44.4 \%$ to $203.6 \%$. Similar CV values have been reported for this feature in Polygonum species (Matusiewicz et al., 2010).

Although the analysed populations of rye brome are phenotypically different, only four groups of homogeneous genotypes were distinguished on the basis of the cluster analysis. Some populations of Bromus secalinus L. growing at close by localities revealed a considerable genetic differences. The most pronounced differences in all traits considered were noted between groups 1 and 4 . On the basis of polymorphism of storage proteins in caryopses of these populations of rye brome only three groups of homogeneous genotypes were distinguished (Skrajna et al., 2012).

Multidimensional statistical analyses permitted characterisation of variation of rye brome population from the localities studied and grouping of objects showing multivariate similarity from the traits analysed. Preservation of phenotypic variation of local forms of plant species is of great importance as it can be used for development of varieties characterised by greater heterozygous state and thus a greater plasticity of harvesting (Kubicka et al., 2006; Sanni et al., 2008). As far as segetal species are concerned, their higher genetic variation permits a better adaptation to a habitat and leads to greater production of seeds per plant, which ensures higher abundance of plants of a given species.

Maintenance of rye brome populations showing high genetic variation needs careful monitoring and control of the historical and present sites of its occurrence.

\section{Conclusions}

Phenotypic variation of the population of Bromus secalinus L. growing at 14 sites in part of North-Eastern Poland, taking into account the following traits: tuft height, number of culms in a tuft, height of generative shoots, length of panicle, number of spikelets in panicle, number of kernels in spikelet, number of kernels in panicle and seed production per plants.

The lowest coefficients of variation were observed for the height of tuft and height of generative shoots for the populations at three sites (1,2 and 3), while the highest coefficient of variation of $203.6 \%$ was found for the plant fertility at site 5 . High 
coefficients of variation attest to a relatively high variation between the rye brome populations studied.

Cluster analysis according to Ward's method permitted distinction of 4 groups of genotypes of multivariate similar populations. The most pronounced differences in the values describing all traits analysed were found between groups 1 and 4 .

On the basis of analysis of spatial autocorrelation with the use of I Moran coefficient, a significant autocorrelation was found for the three following traits: height of generative shoots, length of panicle and number of spikelets in panicle. This result means that the mean values describing the traits were similar for Bromus secalinus populations at close lying sites and the differences increased with increasing distance between the sites compared.

\section{REFERENCES}

[1] Baessler, C, Klotz, S. (2006): Effects of changes in agricultural landuse on landscape structure and arable weed vegetation over the last 50 years. - Agriculture, Ecosystems and Environment 115: 43-50.

[2] Holubec, V. (2010): Monitoring of selected threatened species in Bohemia. - Czech Journal of Genetetics and Plant Breeding 46(Special Issue): S21-S26

[3] Johnson, R.A., Wichern, D.W. (2002): Applied multivariate statistical analysis. 5th ed. Person, Upper Saddle River.

[4] Korniak, T., Dynowski, P. (2009): Bromus secalinus - zanikający czy rozprzestrzeniający się chwast upraw zbożowych w północno-wschodniej Polsce. - In: Proc. XXXIII Kraj. Konf. Nauk. Migracja gatunków i rola chwastów migracyjnych w zbiorowiskach segetalnych oraz biologia gatunków z rodziny Poaceae, Siedlce, 17. (in Polish).

[5] Kubicka, H., Dec, D. (2001): Analiza genetyczna długości i szerokości liścia flagowego i podflagowego u żyta ozimego (Secale cereale L.) [Genetical analysis of length and width of flag and subflag leaf in winter rye (Secale cereale L.)]. - Biuletyn IHAR 218/219: 351360 (in Polish).

[6] Kubicka, H., Puchalski, J., Niedzielski, M., Łuczak, W., Martyniszyn, A. (2006): Gromadzenie i ocena zasobów genowych żyta (Collecting and evaluation of genetic resources of rye). - Biuletyn IHAR 240/241: 141-149 (in Polish).

[7] Matusiewicz, M., Kubicka, H., Wałejko, A., Skrajna, T.(2010): Fenotypowe zróżnicowanie gatunków Polygonum na terenie Suwalszczyzny [Phenotypic diversity of Polygonum species in Suwalszczyzna area]. - Ochrona Środowiska i Zasobów Naturalnych, 2010, 44:58-65 (in Polish).

[8] Mitchell, A. (2005): The ESRI guide to GIS analysis. Vol.2 Spatial measurements and statistics. ESRI Press, Redlands, California.

[9] Moran, P.A.P. (1950): Notes on continuous stochastic phenomena. - Biometrika 37: 1723.

[10] Moray, R. (2005): Bromus-Arten in Winterweizen Verbreitung - Bedeutung und Populationsdynamik - Dissertation zur Erlangung des Grades eines Doktors der Agrarwissenschaften. der Fakultät Agrarwissenschaften der Universität Hohenheim. vor Dipl. Agr.-Biol., p. 136..

[11] Nowak, A., Nowak, S., Spałek, K. (2003): Red list of vascular plants of Opole Province. - Nature Journal - Opole Scientific Society 36: 5-20.

[12] Petersen, J. (2006): Verbreitung, Bedeutung und Bekämpfung von Trespe-Arten im mittleren Westen Deutschlands. - Journal of Plant Diseases and Protection. Zeitschrift für Pflanzenkrankheiten und Pflanzenschutz 20: 289-296.

[13] Pinkie, G., Pál, R. (2008): Phytosociological and conservational study of the arable weed communities in western Hungary. Plant Biosystems 142: 491-508. 
[14] Pysek, P, Jarosik, V, Kropac, Z, Chytrý, M, Wild, J, Tichý, L. (2005): Effects of abiotic factors on species richness and cover in Central European weed communities. Agriculture, Ecosystems and Environment 109: 1-8.

[15] Sanni, K.A., Favole, L., Guei, R.G., Ojo, D.K., Somado, E.A., Tia, D.D., Ogunbayo, S.A., Sanchez, I. (2008): Geographical patterns of phenotypic diversity in Oryza sativa landraces of Côte d'Ivore. - Euphytica 160: 389-400.

[16] Siciński, J.T. (2001): Gatunkowa różnorodność biologiczna chwastów segetalnych i jej zagrożenia w Polsce [Biological diversity segetal weeds species and its threat in Poland]. - Acta Universitatis Lodziensis. Folia Botanica 16: 73-86 (in Polish).

[17] Skrajna, T., Skrzyczyńska, J., Rzymowska, Z. (2005): Występowanie Bromus secalinus L. w agrocenozach Wysoczyzny Kałuszyńskiej [Occurrence of Bromus secalinus L. in agrocenosis of the Kałuszyńska Upland]. - Zeszyty Naukowe Akademii Podlaskiej, Rolnictwo 66/67: 65-73 (in Polish)

[18] Skrajna, T., Kubicka, H., Rzymowska, Z. (2012): Phenotypic variation in relation to seed storage proteins polymorphism in Bromus secalinus 1. populations from the north-eastern Poland. - Polish Journal of Ecology 59: 57-71.

[19] StatSoft, Inc. (2008): STATISTICA (data analysis software system), version 8.0. www.statsoft.com.

[20] Stone, J.C., Peeper, T.F., Stone, A.E. (2006): Rotational cropping systems to reduce cheat (Bromus secalinus) densities. - Weed Technology 20: 445-452.

[21] Šilc, U., Čarni, A. (2007): Formalized classification of the weed vegetation of arable land in Slovenia. Preslia 79: 283-302.

[22] Tichonowa, O.M. (2007): Tipołogia agrofitocenoz ziernowych kultur liwobiepieżnowo lisostiepy (Sumka Obłast) [The typology of agrophytocenoses of grain crops in the leftshore of Ukraine forest-steppe (Sumy region]. - Ukrainian Botanical Journal 64: 840849 (in Ukrainian)

[23] Warcholińska, A.U. (1994): List of threatened segetal plant species in Poland. In:. Mochnacky W.S., Terpo, A. (ed.): Antropization and environment of rural settlements. Flora and vegetation. Proceedings of International Conference. Satoraljaujhely, 206-219.

[24] Zając, M., Zając, A., Tokarska-Guzik, B. (2009): Extinct and endangered archaeophytes and the dynamics of their diversity in Poland. - Biodiversity Research and Conservation 3: $17-24$. 